\title{
Pengaruh Jumlah Uang Beredar dan Jumlah Penduduk Terhadap Pertumbuhan Ekonomi di Indonesia
}

\author{
Risky Meri Yosephina Siburian ${ }^{\mathrm{a}^{*}}$, Murtala $\mathrm{b}^{\text {* }}$ \\ *Fakultas Ekonomi dan Bisnis Universitas Malikussaleh \\ a Corresponding author: riskymeriyosephinasiburian@yahoo.com \\ * tala.murtala@gmail.com
}

A R T I CLE I N F ORMA TION

A B S T R ACT

Keywords:

Money Supply, Population,

Economic Growth, ARDL

Approach.
This study aimes to determine the effect of the money supply and population on economic growth in indonesia in the short and long run. This study uses time series data from 1994 to 2017. The data analysis method used is the Auto Regressive Distributed Lagged (ARDL) approach. The results showed that all variables were co-integrated in the long run. The model stability test results showed that the model used was stable. The results show that all variables were co-integrated in the long run. Partially, in the analysis of short-run money supply had a negative and significant effect on the economic growth in Indonesia, and the population had a positive and significant effect on the value of economic growth in Indonesia. In the long-run, the money supply had a negative and significant effect on the economic growth in Indonesia, and the population had a positive and significant effect on the economic growth in Indonesia.

\section{PENDAHULUAN}

Negara berkembang mempunyai struktur perekonomian yang masih bercorak argraris, rentan dengan adanya guncangan terhadap kestabilan perekonomian. Contoh, seperti negara Indonesia seringkali mengalami guncangan dalam menjaga kestabilan kegiatan perekonomian. Perekonomianmenjadi fokus yang penting dikarenakan bila perekonomian dalam kondisi tidak stabil maka timbul masalah ekonomi seperti rendahnya tingkat pertumbuhan ekonomi, tingginyapengangguran dan tingginya inflasi. Tolak ukur kestabilan perekonomian yaitu dimana jika terjadi pertumbuhan ekonomi, tidak terdapat pengangguran yang tinggi sertaharga barang dan jasa juga tidak terlalu tinggi sehingga menyebabkan terjadinya inflasi.

Berdasarkan data BPS menyatakan bahwa, PDB tahun 2017 sebesar 5,1 persen. Menurut Suhariyanto bahwa, pertumbuhan ekonomi tahun 2017 lebih rendah dariyang ditentukan pada APBN, sebesar 5,2 persen. Namun, diharapkan ekonomi Indonesia ke depan bisa tumbuh lebih tinggi. Diharapkan pada kuartal selanjutnya pertumbuhan ekonomi meningkat, sehingga mampu meningkatkan kesejahteraan rakyat. Pertumbuhan ekonomi pada tahun 2017 merupakan angka tertinggi sejak tahun 2014. pertumbuhan ekonomi tahun 2014 sebesar 5 persen, tahun 2015 sebesar 4,9 persen, dan tahun 2016 sebesar 5 persen, yang artinya hasil infrastruktur mulai bergulir. Sumbangan pertumbuhan ekonomi Indonesia pada tahun 2017 yakni dari industri pengolahan, yaitu 0,91 persen. Selain itu, diikuti sektor konstruksi sebesar 0,67 persen, perdagangan 0,59 persen, dan pertanian 0,49 persen. Diharapkan pertumbuhan dari industri pengolahan, karena dapat meningkatkan pertumbuhan di industri dan dapat menyerap banyak tenaga kerja serta memberikan kontribusi yanglebih besar.

Perekonomian suatu negara tidak terlepas dari kegiatan pembayaran uang. Jika membahas tentang lalu lintas pembayaran uang berarti menyangkut jumlah uang beredar. Perubahan jumlah uang beredar berpengaruh terhadap kegiatan perekonomian di berbagai sektor. Jika jumlah uang beredartinggi, maka menyebabkan inflasi. Kemudian, bila jumlah uang beredar sangat rendah akan menyebabkan kelesuan 
terhadap ekonomi. Jika hal ini terjaditerus menerus, kesejahteraan masyarakatakan menurun (Angraini, 2012).

Para ahli ekonomi yang dipelopori Adam Smithmenyatakan jumlah penduduk ialah inputpotensial yang digunakan sebagai faktor produksi untuk meningkatkan produksi suatu rumah tangga perusahaan. Semakin tinggi jumlah penduduk maka semakin banyaktenaga kerja yang dapat digunakan.

Selain jumlah penduduk, jumlah uang beredar juga turut berpengaruh dalam pertumbuhan ekonomi. Jumlah uang beredar berhubungan positif terhadap pertumbuhan ekonomi. Jika jumlah uang beredar meningkat maka pertumbuhan ekonomi juga akan ikut meningkat. Permintaan uang mempunyai hubungan negatif terhadap output, jika permintaan uang meningkat maka suku bunga akan meningkat dan pada akhirnya akan berakibat terjadinya penurunan output (Natsir, 2014). Berikut adalah data jumlah uang beredar, jumlah penduduk dan pertumbuhan ekonomi di Indonesia dari tahun 2013-2017 pada tabel 1 berikut:

\section{Tabel 1}

Jumlah Uang Beredar, Jumlah Penduduk dan Pertumbuhan Ekonomi di Indonesia tahun 2013-2017

\begin{tabular}{|c|c|c|c|}
\hline Tahun & $\begin{array}{c}\text { Jumlah Uang } \\
\text { Beredar } \\
\text { (Milyar } \\
\text { Rupiah) }\end{array}$ & $\begin{array}{c}\text { Jumlah } \\
\text { Penduduk (Juta } \\
\text { Jiwa) }\end{array}$ & $\begin{array}{c}\text { Pertumbuhan } \\
\text { Ekonomi (\%) }\end{array}$ \\
\hline 2013 & 3.730 .409 & 252.032 .263 & 5,6 \\
\hline 2014 & 4.173 .327 & 255.131 .116 & 5 \\
\hline 2015 & 4.548 .800 & 258.162 .113 & 4,9 \\
\hline 2016 & 5.004 .977 & 261.115 .456 & 5 \\
\hline 2017 & 5.419 .165 & 263.991 .379 & 5,1 \\
\hline
\end{tabular}

Sumber: Bank Indonesia, World Bank.

Berdasarkan pada tabel 1, data jumlah uang beredar dan jumlah penduduk dari tahun 20132017 setiap tahunnya mengalami peningkatan. Dan pertumbuhan ekonomi dari tahun 2013-2017 mengalami fluktuasi, dimana pertumbuhan ekonomi tertinggi terjadi pada tahun 2013 sebesar $5,6 \%$ dan pertumbuhan ekonomi terendah terjadi pada tahun 2015 sebesar $4,9 \%$. Sedangkan yang dijelaskan dalam teori, hubungan antara pertumbuhan ekonomi dan jumlah uang beredar memiliki hubungan positif begitu juga dengan jumlah penduduk dan pertumbuhan ekonomi. Tetapi yang terjadi ialah JUB dan jumlah penduduk meningkat, sedangkan PE mengalami fluktuasi tiap tahunnya.

Tujuan penelitian ini untuk mengetahui bagaimana pengaruh jumlah uang beredar dan jumlah penduduk terhadap pertumbuhan ekonomi di Indonesia.

Selanjutnya bagian kedua penelitian ini membahas tinjauan teoritis variabel-variabel terkait, pembatasan kajian dan alat analisis dipaparkan dibagian ketiga, untuk melihat hasil dan pembahasan dapat dilihat pada bagian keempat. Akhirnya pada bagian kelima merupakan kesimpulan dan saran.

\section{TINJAUAN TEORITIS}

\section{Pertumbuhan Ekonomi}

Pertumbuhan ekonomi ialah perkembangan kegiatan perekonomian yang mengakibatkan barang dan jasa diproduksikan pada masyarakat bertambahdan kesejahteraan meningkat. Menurut Boediono, (2008) pertumbuhan ekonomi ialah proses dari kenaikan dalam jangka panjang sebagai persentase dalam pertambahan output haruslah lebih besar daripadajumlah penduduk dan pertumbuhan ekonomi tersebut akan terus berlanjut.

Menurut (Machmud, 2016) yang digunakan untuk mengukur pertumbuhan ekonomi adalah pertumbuhan tahunan dan pertumbuhan rata-rata, pertumbuhan ekonomi tahunan diukur menggunakan rumus sebagai berikut:

keterangan:

$$
\mathrm{g}=\left(\frac{\mathrm{PDBs}-\mathrm{PDBk}}{P D B k}\right) \times 100 \%
$$

$$
\begin{array}{ll}
\mathrm{g} & =\text { Tingkat Pertumbuhan Ekonomi } \\
\mathrm{PDB}_{\mathrm{s}} & =\mathrm{PDB} \text { riil tahun berjalan } \\
\mathrm{PDB}_{\mathrm{k}} & =\text { PDB riil tahun sebelumnya }
\end{array}
$$

Para ahli ekonomi berpendapat bahwa ada beberapa faktor lain yang ikut mempengaruhi pertumbuhan ekonomi, contohnya: luas tanah, tingkat kekayaan alam dan teknologi yang digunakan. Para ahli ekonomi klasik memfokuskan perhatian mereka kepada pengaruh jumlah penduduk terhadap pertumbuhan ekonomi meskipun mereka sangat menyadari jika pertumbuhan ekonomi juga dapat dipengaruhi oleh banyak faktor lainnya (Alghofari, 2007).

Menurut Schumpeter dalamErvani, (2004)mengatakan bahwa pertumbuhan ekonomi yaitu proses peningkatan output pada masyarakat yang disebabkan dari semakin bertambahnya faktor produksi yang digunakan untuk proses produksi pada masyrakat tanpa harus terjadi 
adanya perubahan dari teknologi itu sendiri. Pembangunan ekonomi merupakan proses kenaikan dari output yang terjadi akibat adanya inovasi yang dibuat oleh wiraswasta.

Schumpeter mengumukakan sistem kapitalis adalah sistem yang sangat bagus untuk memperbaiki pembangunan ekonomi. Proses inovasi yang dibuat oleh para pelaku wiraswasta adalah salah satu faktor yang paling utama yang bisa menyebabkan terjadinya perkembangan ekonomi.

Sukirno (2010) menyebutkan analisis yang digunakan oleh Harrod-Domar adalah pemisalanpemisalan, contohnya: (i) barang modal mencapai kapasitas penuh (ii) tabungan ialah proporsional dengan pendapatan nasional (iii) rasio modal produksi tetap nilainya, dan (iv) perekonomian dua sektor. Dalam analisis Harrod-Domar menunjukkan pada tahun tertentu barang modal sudah mencapai kapasitas penuh. Perekonomian pada dasarnya senantiasa menabung sebagian dari pendapatan nasional untuk menambah ataupun menggantikan barang modal yang telah rusak. Namun untuk mengacu perekonomian, diperlukan pula investasi baru untuk tambahan neto terhadap cadangan (Todaro, 2003).

\section{Jumlah Uang Beredar}

MenurutNatsir(2014), uang beredar diartikansebagai kewajiban sistem moneter terhadap sektor swasta domestik.

Uang terdiri dari dua jenis yaitu uang logam dan uang kertas.Uang beredar atau money supply dibedakan menjadi dua pengertian yaitu dalam arti sempit (M1) dan dalam arti luas (M2).

1. Uang beredar dalam arti sempit (M1)

$$
\text { M1 = uang kartal + uang giral }
$$

2. Uang beredar dalam arti luas (M2)

$$
\mathrm{M} 2=\mathrm{M} 1+\text { uang kuasi }(\mathrm{T})
$$

Selanjutnya dalamteori kuantitas uang sebenarnya merupakan teori mengenai permintaan dan juga penawaran akan uang, serta interaksi antara keduanya.

\section{Teori Kuantitas Irving Fisher}

Fisher mengatakan aspek moneter merupakan faktor penting terjadinya inflasi. Teori mengenai kuantitas uang banyak yang mengacu pada hukum kuantitas uang dari Fisher yang dituliskan sebagai berikut (Imamudin Yuliadi, 2008):

$\mathrm{MV}=\mathrm{PT} .$.

(2.1)

di mana:

M : Jumlah Uang Beredar

$\mathrm{V}$ : Tingkat perputaran uang,
P : Harga Barang

$\mathrm{T}$ : volume barang yang di transaksikan

\section{Teori Cambridge (Marshall-Pigou)}

Perbedaan teori Cambridge dan teori Fisher terletak dalam teori permintaan uang, Cambridge mengalokasikan kekayaannya dalam berbentuk uang.Teori Cambridge menyatakan bahwa kegunaan memegang kekayaan dalam bentuk uang ialah karena uang mudah ditukarkan dengan barang lain. Teori Cambridge menganggap bahwa, ceteris paribus permintaan akan uang adalah proporsional dengan tingkat pendapatan nasional (Imamudin Yuliadi, 2008).

$\mathrm{Md}=f(\mathrm{k}, \mathrm{P}, \mathrm{Y})$.

di mana:

$\mathrm{Y}$ adalah pendapatan nasional riil

$P$ adalah tingkat harga umum

$\mathrm{k}$ adalah jumlah kekayaan.

\section{Teori Keynes}

Teori Keynes yang bersumber pada teori Cambridge, mengemukakan hal berbeda dengan teori moneter klasik. Dalam analisis Keynes masyarakat memegang uang untuk tiga tujuan antara lain:
a) transaksi
b) berjaga-jaga
c) untuk spekulasi

Jumlah uang beredar berhubungan positif terhadap pertumbuhan ekonomi. Jika jumlah uang beredar terjadi peningkatan maka pertumbuhan ekonomi juga akan ikut meningkat. Hal tersebut sesuai dengan hipotesa dari Keynes yang mengatakan bahwa penawaran uang mempunyai pengaruh positif terhadap output dan pertumbuhan ekonomi. Jika jumlah uang beredar pada masyarakat mengalami kelebihan, maka biasanya Bank Indonesia mengambil keputusan atau kebijakan untuk menurunkan suku bunga. Kondisi seperti ini sering mendorong para investor melakukan investasi,selanjutnya dapat menciptakan peningkatan output dan mendorong pertumbuhan ekonomi. Permintaan uang mempunyai hubungan negatif terhadap output, jika permintaan uang meningkat maka juga berdampak terhadap penigkatan tingkat suku bunga yang akhirnya akan berakibat terjadinya penurunan output (Natsir, 2014).

\section{Jumlah Penduduk}

Penduduk adalah sejumlah orang yang tinggal disuatu tempat yang terikat oleh aturan- 
aturan yang berlaku dan saling berinteraksi satu sama lain secara terus-menerus atau continue.

Penduduk yaitu sejumlah orang yang tinggal di wilayah geografis selama 6 bulan atau lebih dan mereka yang berdomisili kurang dari 6 bulanbertujuan untuk menetap (BPS 2014). Menurut Chairany, (2010)penduduk yaitu sejumlah orang yang berdomisili/tinggal di wilayah geografis Indonesia selama enam bulan atau lebih dan atau mereka yang berdomisili kurang dari enam bulan dan bertujuan menetap.

Jumlah penduduk suatu negara tidak stabil karena terdapat faktor yang mempengaruhi seperti fertilitas, mortalitas dan migrasi.

model Kremerian memberikan pendapat bahwa pertumbuhan jumlah penduduk adalah kunci dalam menunjukkan kesejahteraan ekonomi. Model ini beranggapan sama dengan model Nasionalis yang artinya pertumbuhan jumlah penduduk akan meningkatkan pembangunan.

Kinerja perekonomian suatu wilayah tidak terlepas dari unsur kependudukan yang berdomisili/tinggal di wilayah tersebut. Penduduk merupakan pelaku utama kegiatan ekonomi di wiliyah, oleh sebab itu struktur kependudukan sedikit banyak akan memepengaruhi profil dan kinerja kegiatan ekonomi wilayah yang bersangkutan. Jumlah penduduk, struktur umur, jenis kelamin dan Pendidikan merupakan data umum yang sering digunakan untuk menunjukkan potensi sumberdaya manusia suatu wilayah. (Setiono, 2011).

\section{Kerangka Konseptual}

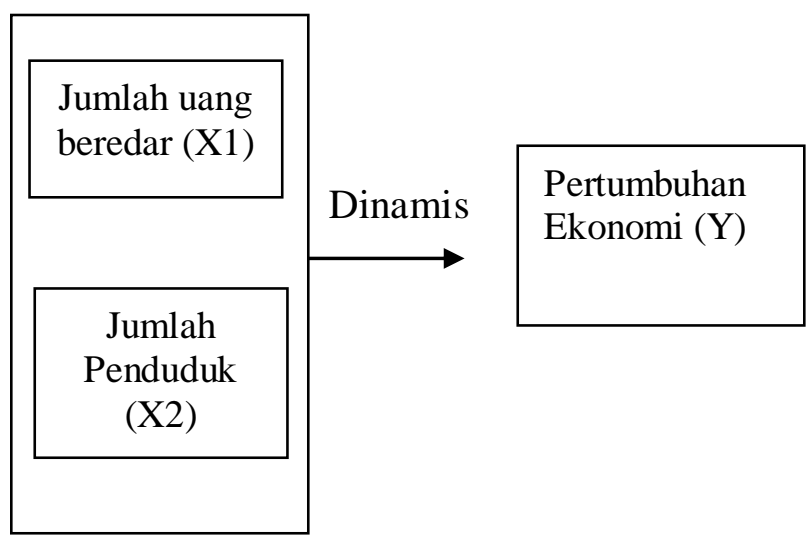

\section{Gambar 1}

Kerangka Konseptual

Berdasarkan kerangka konseptual penelitian ini menggunakan variabel independent jumlah uang beredar sebagai X1 dan jumlah penduduk sebagai $\mathrm{X} 2$ berpengaruh terhadap pertumbuhan ekonomi sebagai variabel dependent (Y). Secara parsial masing-masing akan diuji dengan menggunakan uji t. Sedangkan secara simultan akan digunakan uji $\mathrm{F}$.

\section{Hipotesis}

Hipotesis adalah jawaban sementara atas objek-objek penelitian yang sedang diteliti. Berikut hipotesis dalam penelitian ini:

1. Diduga jumlah uang beredar berpengaruh negatif dan signifikan dalam jangka pendek dan jangka panjang terhadap pertumbuhan ekonomi di Indonesia.

2. Diduga jumlah uang beredar berpengaruh positif dan signifikan dalam jangka pendek dan jangka Panjang terhadap pertumbuhan ekonomi di Indonesia.

3. Diduga jumlah penduduk berpengaruh negatif dan signifikan dalam jangka pendek dan jangka panjang terhadap pertumbuhan ekonomi di Indonesia.

4. Diduga jumlah penduduk berpengaruh positif dan signifikan dalam jangka pendek dan jangka panjang terhadap pertumbuhan ekonomi di Indonesia.

\section{METODE PENELITIAN Data dan Sumber Data}

Penelitian ini menggunakan data kuantitatif, yaitu data yang dapat diukur dalam skala numerik atau dalam bentuk angka. Penelitian ini menggunakan data sekunder dengan bentuk data time-series yaitu dalam bentuk tahunan dengan tahun pengamatan selama 24 tahun yaitu dari tahun 1994-2017.

\section{Defenisi Operasional Variabel}

Penelitian ini meletakkan pertumbuhan ekonomi sebagai variabel terikat, sedangkan jumlah uang beredar dan jumlah penduduk sebagai variabel bebas. Defenisi operasional variabel yaitu:

a. Pertumbuhan Ekonomi (Y)

Pertumbuhan Ekonomi (PE) yaitu suatu proses dari perubahan keadaan perekonomian di sebuah negara secara berkesinambungan menuju kondisi yang lebih baik selama tahun tertentu.

b. Jumlah Uang Beredar (X1)

Jumlah uang beredar ialah kondisi dimana sejumlah uang yang mengalami perputaran di lokasi perekonomian seperti pasar.

c. Jumlah Penduduk (X2)

Jumlah penduduk adalah sejumlah orang yang tinggal di wilayah geografis selama 6 
bulan atau lebih dan mereka yang berdomisili kurang dari 6 bulan serta bertujuan untuk menetap (BPS, 2014).

\section{Metode Analisis Data}

Adapun metode analisis data yang dipakai yaitu model ARDL (Auto Regressive Distributed Lag). Model ARDL merupakan gabungan antara model AR) dan DL. Model AR yaitu model yang memakaisatu ataupunlebih data masa lampau dari variabel terikat. Sedangkan model DL yaitu model regresi yang melibatkan data pada waktu sekarang dan waktu masa lampau (Gujarati \& Porter, 2012). Dalam penelitian ini penulis menggunakan model ARDL di mana diartikan sebagai sebuah model yang menggunakan waktu data pada waktu masa lampau dan masa sekarang yang terdiri dari variabel bebas dan variabel terikatnya.

Adapun persamaan ARDL secara umum adalah sebagai berikut:

$$
\begin{aligned}
& \Delta P e_{t}=\alpha_{0 \mathrm{i}}+\sum_{i=1}^{n} \alpha_{1 \mathrm{i}} \Delta \mathrm{Pe}_{t-i}+\sum_{i=1}^{n} \alpha_{2 \mathrm{i}} \Delta \mathrm{Jub}_{t-i}+\sum_{i=1}^{n} \alpha_{3 i} \Delta \mathrm{Jp}_{t-i}+\beta_{11} P e_{t-1} \\
& +\beta_{21} J u b_{t-1}+\beta_{31} J p_{t-1}+\varepsilon_{1 \mathrm{t}}
\end{aligned}
$$

Persamaan ARDL dalam jangka pendek adalah sebagai berikut:

$$
\begin{gathered}
\Delta P e_{t}=\alpha_{0 \mathrm{i}}+\sum_{i=1}^{n} \alpha_{1 \mathrm{i}} \Delta \mathrm{Pe}_{t-i}+\sum_{i=1}^{n} \alpha_{2 \mathrm{i}} \Delta \mathrm{Jub}_{t-i}+\sum_{i=1}^{n} \alpha_{3 \mathrm{i}} \Delta \mathrm{Jp}_{t-i}+\alpha_{4 \mathrm{i}} \Delta E c t_{t-1} \\
+\varepsilon_{1 \mathrm{t}}
\end{gathered}
$$

Uji jangka pendek:

$$
\begin{aligned}
& \mathrm{H}_{\mathrm{o}}: \mathrm{a}_{1 \mathrm{i}}=\mathrm{a}_{2 \mathrm{i}}=\mathrm{a}_{3 \mathrm{i}}=0 \\
& \mathrm{H}_{\mathrm{a}}: \mathrm{a}_{1 \mathrm{i}} \neq \mathrm{a}_{2 \mathrm{i}} \neq \mathrm{a}_{3 \mathrm{i}} \neq 0
\end{aligned}
$$

Dimana $\alpha_{1 i} \alpha_{2 \mathrm{i}}$ dan $\alpha_{3 \mathrm{i}}$ merupakan koefisien dinamis jangka pendek yaitu kecepatan penyesuaian keseimbangan.

Persamaan ARDL dalam jangka panjang adalah sebagai berikut:

$$
\Delta P e_{t}=\beta_{0 \mathrm{i}}+\beta_{11} P e_{t-1}+\beta_{21} J u b_{t-1}+\beta_{31} J p_{t-1}+\varepsilon_{1 \mathrm{t}}
$$

Uji Jangka Panjang:

$\mathrm{H}_{\mathrm{o}}: \beta_{1 \mathrm{i}}=\beta_{2 \mathrm{i}}=\beta_{3 \mathrm{i}}=0$

$\mathrm{H}_{\mathrm{a}}: \beta_{1 \mathrm{i}} \neq \beta_{2 \mathrm{i}} \neq \beta_{3 \mathrm{i}} \neq 0$

Dimana $\beta_{1 i} \beta_{2 i}$ dan $\beta_{3 i}$ merupakan koefisien dinamis jangka panjang.

Dimana:

$$
\begin{array}{ll}
\mathrm{Pe} & =\text { Pertumbuhan Ekonomi } \\
\mathrm{Jub} & =\text { Jumlah Uang Beredar } \\
\mathrm{Jp} & =\text { Jumlah Penduduk }
\end{array}
$$

\section{Uji Stasioneritas}

Uji Stasioneritas data merupakan syarat penting bagi analisis data time series untuk menghindari regresi lancung (sporious regression). Dalam penelitian ini uji stasioneritas data menggunakan Augmented Dickey-Fuller (ADF) pada derajat yang sama (level atau different) hingga diperolehsuatu data yang stasioner. Data dapat dikatakan stasioner bila memenuhi tiga syarat, yaitu rata-rata dan variannya konstan sepanjang waktu, serta kovarian antar data hanya tergantung pada (lag) (Widarjono, 2007).

\section{Penentuan Lag Optimum}

Penentuan jumlah lag ditentukan pada kriteria informasi yang direkomendasikan oleh Final Prediction Error (FPE), Aike Information Criterion (AIC), Schwarz Criterion (SC), dan Hannan Quinn (HQ). Dimana hasil dalam uji panjang lag (Lag Length) ditentukan dengan jumlah bintang terbanyak yang direkomendasi dari masing-masing kriteria uji lag length.

\section{Uji Kointegrasi}

Data time series seringkali memperlihatkan keadaan yang tidak stasioner pada tingkat level (Widarjano, 2013). Namun seringkali menunjukkan satasioner melalui tingkat difference. Oleh karena itu perlu dilakukan uji kointegrasi untuk melihati apakah variabel bebas dan terikat terkointegrasi sehingga ada hubungan jangka panjang antar variabel.Untukmelihat kointegrasi maka dilakukan melalui uji Bound Test. Apabila F-statistik lebih besar dari nilai kritikal value maka Ho yang menyatakan tidak ada kointegrasi ditolak, artinya ada kointegrasi dan apabila nilai F-statistik kurang dari lower bound maka Ho tidak dapat ditolak, artinya tidak ada kointegrasi, dan apabila F-statistik berada diantara upper dan lower bound maka kesimpulan tidak dapat diambil (Widarjono, 2013).

\section{Uji Stabilitas Model}

Untuk melihat model dalam penelitian ini stabil atau tidak maka akan dilakukan uji stabilitas structural model. Pengujian tersebut terdiri dari uji CUSUM dan uji CUSUMQ. Pembuktian ini bisa dilihat dari plot kuantitas $\mathrm{Wr}$ dan $\mathrm{Sr}$ melewati garis batas yang ditentukan oleh tingkat signifikansi. Apabia plot tersebut membentuk garis linier, maka distribusinya dianggap memenuhi syarat signifikansi dengan syarat tidak melewati plot derajat dari signifikansinya.

\section{Pengujian Statistik}

\section{Uji Statistik t}

Uji t untuk mengetahui signifikansi dari pengaruh variabel bebas secara individu terhadap variabel terikat (Gujarati, 2006). Adapun kriteria pengujiannya yaitu sebagai berikut: 
1. Jika $t_{\text {hitung }}>t_{\text {tabel }}$ maka Ho ditolak dan menerima Ha yang artinya variabel bebas (X) secara parsial mempengaruhi variabel terikat (Y).

2. Jika $t_{\text {hitung }}<t_{\text {tabel }}$ maka Ho diterima dan menolak Ha yang artinya variabel bebas (X) secara parsial tidak mempengaruhi variabel terikat (Y)

\section{Uji Statistik F}

Uji F untuk melihat apakah variabel bebas secara serentakmempengaruhi variabel terikat. Apabila uji $\mathrm{F}$ lebih besar daripada nilai tabel $F$ maka variabel bebas secara keseluruhan berpengaruh terhadap variabel terikat (Gujarati, 2006). Adapun kriteria pengujian yang dipakaiyaitu sebagai berikut:

1. Jika $F_{\text {hitung }}>F_{\text {tabel }}$ maka Ho ditolak dan menerima Ha yang artinya variabel bebas (X) secara simultan mempengaruhi variabel terikat (Y).

3. Jika $F_{\text {hitung }}<F_{\text {tabel }}$ maka Ho diterima dan menolak Ha yang artinya variabel bebas (X) secara simultan tidak mempengaruhi variabel terikat (Y)

\section{Koefisien Determinasi}

Koefisien determinasi $\left(R^{2}\right)$ pada intinya menghitung seberapa besar kemampuan model untuk bisamenjelaskan variasi variabel terikat. Nilai koefisien determinasi yaitu antara nol dan satu $\left(0<R^{2}<1\right)$. (Gujarati, 2006).

\section{HASIL PENELITIAN DAN PEMBAHASAN}

Sesuai dengan tujuan peneliti terkait apa yang telah dilakukan, diamati, dipaparkan dan yang telah dianalisis pada bab sebelumnya. Uraian pada bab ini telah dikaitkan dengan hasil kajian teori dan penelitian-penelitian yang relevan terhadap penelitian ini.

\section{Uji Stasioner Data}

Untuk mengetahui data time series yang dipakai stasioner atau tidak, digunakan uji akarakar unit dengan menggunakan metode ADF. Apabila pengujian ditingkat level menunjukkan data tidak stasioner maka dapat dilakukan pengujian di tingkat first difference untuk melihat kelayakan model yang digunakan sebagai penelitian yaitu ARDL (Auto Regresive Distributed Lag). Stasioner atau tidaknyaterlihat dari nilai probabilitasnya (Critical Value) yang dibandingkan pada tingkat alpha $(1 \%, 5 \%$, atau $10 \%)$.
Tabel 2

Unit Root Test denganADF

\begin{tabular}{|c|c|}
\hline Variabel & Level \\
\hline PE & 0.0093 \\
\hline LnJUB & 0.0530 \\
\hline JP & 0.0432 \\
\hline
\end{tabular}

Sumber: hasil pengolahan Data, 2019

Berdasarkan Tabel 2 dapat dijelaskan bahwa hasil uji unit root pada tingkat signifikansi 5 persen variabel PE, LnJUB dan JP stasioner pada Level. Karena variabel PE, LnJUB dan JP memiliki nilai probabilitas $\mathrm{ADF}<$ dari tingkat pengujian alpha 5 persen. Dengan demikian variabel PE, LnJUB dan JP stasioner pada tingkat Level.

Berdasarkan hasil pengujian stasioneritas maka model ARDL merupakan metode yang cocok digunakan dalam penelitian ini.

\section{Penentuan Lag Optimal}

Pemilihan lag optimal pada penelitian ini berdasarkan metode VAR. Dalam penetapan lag optimal digunakan nilai dari Likelihood Ratio (LR), Final Prediction Error (FPE), Akaike Information Criterion (AIC), Schwarz Information Criterion (SC), dan Hannan-Quin Criterion (HQ). Adapun panjang lag optimal yang dipilih berdasarkan kriteria-kriteria di atas ditunjukkan pada Tabel 3

Tabel 3

\section{Panjang Lag Berdasarkan Beberapa Kriteria}

\begin{tabular}{|c|c|c|c|c|c|c|}
\hline Lag & $\log \mathrm{L}$ & LR & FPE & AIC & $\mathrm{SC}$ & HQ \\
\hline 0 & -440.7314 & NA & $6.63 e+13$ & \begin{tabular}{|l|}
40.339 \\
22
\end{tabular} & 40.48800 & 40.37426 \\
\hline 1 & -292.7260 & $7^{242.190}$ & $2.18 \mathrm{e}+08$ & $\begin{array}{l}27.702 \\
36\end{array}$ & $8^{28.2974}$ & $5^{27.8425}$ \\
\hline 2 & -238.4428 & 74.02257 & $3762980^{*}$ & \begin{tabular}{|l|}
23.585 \\
$71 *$
\end{tabular} & ${ }_{*}^{24.62716}$ & ${ }_{*}^{23.83104}$ \\
\hline
\end{tabular}

Sumber: Hasil Pengolahan Data, 2019

Berdasarkan Tabel 3 output VAR Lag Order Selection CriteriaLR, FPE, AIC, SC, dan HQ memilih lag order 2ditetapkan sebagai lag yang optimal untuk dipergunakan dalam estimasi terhadap persamaan umum ARDL. Adapun maksud dari lag optimal pada penelitian ini ialah bahwa semua variabel penelitian yang dipergunakan dalam persamaan saling mempengaruhi satu sama lain sampai tiga periode sebelumnya.

\section{Uji Kointegrasi(Cointegration Test)}

Untuk mengetahui hasil uji kointegrasi dengan memakai metode bounds test bisa dilihat 
pada Tabel 4.

Tabel 4

Hasil Uji Kointegrasi (Bounds Test)

\begin{tabular}{|l|l|l|l|l|}
\hline $\begin{array}{l}\text { Variabel } \\
\text { Dependen/ } \\
\text { Independen }\end{array}$ & $\begin{array}{l}\text { Nilai } \\
\text { F-Statistik }\end{array}$ & \multicolumn{2}{|l|}{$\begin{array}{l}\text { Taraf } \\
\text { Kepercayaan5\% }\end{array}$} & \multirow{2}{*}{$\begin{array}{l}\text { Kesimpula } \\
\text { n }\end{array}$} \\
\cline { 3 - 4 } & $\begin{array}{l}\text { I0 } \\
\text { Bound }\end{array}$ & $\begin{array}{l}\text { I1 } \\
\text { Bound }\end{array}$ & \\
\hline PE / LnJUB, JP & 14.17391 & 3.1 & 3.87 & Terima Ha \\
\hline
\end{tabular}

Sumber: Hasil Pengolahan Data, 2019

Berdasarkan Tabel 4 diperoleh hasil pengujian kointegrasi dengan memakai metode bound test pada taraf kepercayaan $5 \%$ yaitu variabel PE (sebagai variabel terikat), LnJUB dan JP(sebagai variabel bebas) terdapat kointegrasi dalam jangka panjang karena memiliki nilai FStatistik lebih besar dari pada nilai kritikal dari upper bound yaitu 14.17391> 3.87.

\section{Hasil Penelitian Untuk Hubungan Jangka Pendek}

Untuk melihat pengaruh jumlah Uang Beredar dan Jumlah Penduduk terhadap pertumbuhan ekonomi di negara Indonesia bisa dilihat pada Tabel 5

\section{Tabel 5}

\section{Estimasi Model ARDL Jangka Pendek}

\begin{tabular}{crlrr}
\hline \hline Variable & Coefficient & Std. Error & t-Statistic & Prob. $^{*}$ \\
\hline \hline PE(-1) & 0.208326 & 0.153021 & 1.361428 & 0.1949 \\
PE(-2) & -0.441493 & 0.086062 & -5.129963 & 0.0002 \\
LNJUB & -51.96432 & 4.118663 & -12.61679 & 0.0000 \\
LNJUB(-1) & 44.02312 & 9.241789 & 4.763484 & 0.0003 \\
LNJUB(-2) & -14.11441 & 6.187408 & -2.281150 & 0.0387 \\
JP & $1.91 \mathrm{E}-05$ & $3.41 \mathrm{E}-06$ & 5.592474 & 0.0001 \\
JP(-1) & $-1.81 \mathrm{E}-05$ & $3.32 \mathrm{E}-06$ & -5.460367 & 0.0001 \\
C & 48.17161 & 14.96899 & 3.218093 & 0.0062 \\
\hline \hline R-squared & 0.943743 & Mean dependent var & 4.321364 \\
Adjusted R-squared & 0.915614 & S.D. dependent var & 4.107165 \\
S.E. of regression & 1.193100 & Akaike info criterion & 3.466274 \\
Sum squared resid & 19.92882 & Schwarz criterion & 3.863017 \\
Log likelihood & -30.12902 & Hannan-Quinn criter. & 3.559735 \\
F-statistic & 33.55101 & Durbin-Watson stat & 2.632812 \\
Prob(F-statistic) & 0.000000 & & & \\
\hline \hline
\end{tabular}

Sumber: Hasil Pengolahan Data, 2019

Berdasarkan hasil pengujian jangka pendek dengan memakai model ARDL pada tabel maka dapat diformulasikan sebagai berikut:

$\mathrm{PE}=48.17161-51.96432 \mathrm{LNJUB}+0.00000191 \mathrm{JP}$ Adapun interpretasi persamaannya adalah sebagai berikut:

1. constanta $=48.17161$

apabila jumlah uang beredar dan jumlah penduduk bernilai konstan maka pertumbuhan ekonomi juga akan konstan sebesar 48.17161 persen.

2. Koefisien LNJUB $=-51.96432$
Apabila jumlah uang beredar meningkat 1 persen maka pertumbuhan ekonomi akan menurun sebesar 51.96432 persen.

3. Koefisien JP $=0.00000191$

Apabila jumlah penduduk meningkat sebesar 1 persen maka pertumbuhan ekonomi akan meningkat sebesar 0.00000191 persen.

\section{Hasil Penelitian Untuk Hubungan Jangka Panjang}

Untuk mengetahui pengaruh jumlah uang beredar dan jumlah penduduk terhadap pertumbuhan ekonomi di Indonesia dapat dilihat pada Tabel 6

Tabel 6

Estimasi Model ARDL Jangka Panjang

\begin{tabular}{|c|c|c|c|c|}
\hline \multicolumn{5}{|c|}{ Conditional Error Correction Regression } \\
\hline Variable & Coefficient & Std. Error & t-Statistic & Prob. \\
\hline C & 48.17161 & 14.96899 & 3.218093 & 0.0062 \\
\hline $\operatorname{PE}(-1)^{*}$ & -1.233167 & 0.167188 & -7.375934 & 0.0000 \\
\hline LNJUBB $(-1)$ & -22.05560 & 3.931923 & -5.609369 & 0.0001 \\
\hline$J P(-1)$ & $9.42 \mathrm{E}-07$ & $1.70 \mathrm{E}-07$ & 5.536337 & 0.0001 \\
\hline $\mathrm{D}(\mathrm{PE}(-1))$ & 0.441493 & 0.086062 & 5.129963 & 0.0002 \\
\hline D(LNJUB) & -51.96432 & 4.118663 & -12.61679 & 0.0000 \\
\hline $\mathrm{D}(\mathrm{LNJUB}(-1))$ & 14.11441 & 6.187408 & 2.281150 & 0.0387 \\
\hline $\mathrm{D}(\mathrm{JP})$ & $1.91 \mathrm{E}-05$ & $3.41 \mathrm{E}-06$ & 5.592474 & 0.0001 \\
\hline \multicolumn{5}{|c|}{ * $\mathrm{p}$-value incompatible with $\mathrm{t}$-Bounds distribution. } \\
\hline \multicolumn{5}{|c|}{$\begin{array}{l}\quad \text { Levels Equation } \\
\text { Case 2: Restricted Constant and No Trend }\end{array}$} \\
\hline Variable & Coefficient & Std. Error & $\mathrm{t}$-Statistic & Prob. \\
\hline LNJUB & -17.88534 & 1.951194 & -9.166357 & 0.0000 \\
\hline JP & 7.64E-07 & 8.40E-08 & 9.088159 & 0.0000 \\
\hline C & 39.06335 & 10.35440 & 3.772632 & 0.0021 \\
\hline
\end{tabular}

Sumber: Hasil Pengolahan Data, 2019

Berdasarkan hasil pengujian jangka panjang dengan menggunakan model ARDL pada tabel maka dapat diformulasikan sebagai berikut: $\mathrm{PE}=39.0633-17.8853 \mathrm{LNJUB}+0.0000000764 \mathrm{JP}$ Adapun intepretasi persamaannya adalah sebagai berikut:

1. Constanta $=39.0633$

Apabila jumlah uang beredar dan jumlah penduduk bernilai konstan maka pertumbuhan ekonomi juga akan konstan sebesar 39.0633persen.

2. $\beta_{1}=-17.8853$

Apabila jumlah uang beredar meningkat sebesar 1 persen maka pertumbuhan ekonomi akan menurun sebesar 17.8853persen.

3. $\beta_{2}=-0.0000000764$

Apabila jumlah penduduk meningkat sebesar 1 persen maka pertumbuhan ekonomi akan meningkat sebesar $0.0000000764 J P$ persen. 


\section{Pembuktian Secara Parsial (Uji t)}

Uji t bertujuan untuk mengetahui koefisienkoefisien masing-masing variabel bebas signifikan ataupun tidak terhadap variabel terikatnya secara parsial. Dalam uji $\mathrm{t}$ harus ditentukan derajat kebebasan (df) yang mana didapatkan dari jumlah sampel dikurangi dengan jumlah regresor (variabel). Pada penelitian ini didapat $\mathrm{df}=(\mathrm{n}-\mathrm{k})$ $(24-3=21)$ pada alfa $5 \%(0,05)$ maka didapat nilai t-tabel adalah 2,07961 atau 2,07. Apabila $t_{\text {hitung }}$ lebih besar dari pada $t_{\text {tabel }}$ maka terima Ha yang artinya variabel bebas secara parsial berpengaruh terhadap variabel terikat, sedangkan Apabila $t_{\text {hitung }}$ lebih kecil dari pada $t_{\text {tabel }}$ maka terima Ho yang artinya variabel bebas tidak berpengaruh terhadap variabel terikat.

\section{Tabel 7}

\section{Hasil Pengujian Secara Parsial}

\begin{tabular}{|c|c|c|c|c|}
\hline $\begin{array}{c}\text { Dependent } \\
\text { Variabel PE }\end{array}$ & t-Statistik & Prob & t table & Kesimpulan \\
\hline \multicolumn{5}{|l|}{ Jangka Pendek } \\
\hline $\mathrm{D}$ (LNJUB) & $-12,61679$ & 0,0000 & \multirow{2}{*}{2,07} & $\begin{array}{c}\text { Terima } \\
\text { H1 }\end{array}$ \\
\hline $\mathrm{D}(\mathrm{JP}))$ & 5,592474 & 0,0001 & & Terima $\mathrm{H} 2$ \\
\hline \multicolumn{5}{|l|}{ Jangka Panjang } \\
\hline LNJUB & $-9,166357$ & 0,0000 & \multirow{2}{*}{2,07} & Terima H3 \\
\hline JP & 9,088159 & 0,0000 & & Terima H4 \\
\hline
\end{tabular}

Sumber: Hasil Pengolahan Data, 2019

Berdasarkan Tabel 7 di atas menunjukkan pada jangka pendek variabel jumlah uang beredart $_{\text {hitung }}$ lebih besar dari pada $t_{\text {tabel }}$ yaitu 12,61679>2,07 maka terima $\mathrm{H} 1$ yang artinya variabel jumlah uang beredar secara parsial berpengaruh terhadap pertumbuhan ekonomi, begitu juga dengan variabel jumlah penduduk

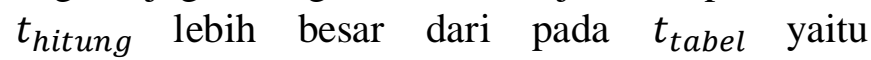
$5,592474<2,07$ maka terima $\mathrm{H} 2$ yang artinya variabel jumlah penduduk secara parsialberpengaruh terhadap pertumbuhan ekonomi.

Pada jangka panjang variabel jumlah uang beredart $_{\text {hitung }}$ lebih besar dari pada $t_{\text {tabel }}$ yaitu 9,166357>2,07 maka terima $\mathrm{H} 3$ yang artinya variabel jumlah uang beredar secara parsial berpengaruh terhadap pertumbuhan ekonomi. Begitu juga dengan variabel jumlah penduduk $t_{\text {hitung }}$ lebih besar dari pada $t_{\text {tabel }}$ yaitu 9,088159 > 1,70 maka terima $\mathrm{H} 4$ yang artinya variabel jumlah penduduk secara parsial berpengaruh terhadap pertumbuhan ekonomi.
Berdasarkan hasil pengujian yang dilakukan yang terdapat pada tabel di atas maka dapat diketahui bahwa nilai F-statistik sebesar 33,55101 pada taraf kepercayaan 5\%, sementara Ftabel V1=n-k $(24-3=21)$ dan V2=k-1 $(3-1=2)$ di peroleh nilai sebesar 3,47 maka F-statistik > Ftabel yaitu 33,55>3,47. Kesimpulan hipotesis adalah terima Ha yang berarti secara simultan atau bersama-sama jumlah uang beredar dan jumlah penduduk berpengaruh signifikan terhadap pertumbuhan ekonomi di Indonesia.

\section{Koefisien Determinasi $\boldsymbol{R}^{\mathbf{2}}$}

Berdasarkan hasil penelitian menyebutkan bahwa nilai koefisien determinasi untuk analisis ARDL yaitu 0,915614. Hal ini menunjukkan kemampuan model dalam menjelaskan hubungan variabel bebas yaitu jumlah uang beredar dan jumlah penduduk adalah sebesar 0,915614 atau 91,56 persen. Sedangkan jumlah yang tersisa yaitu 0,8 persen dipengaruhi oleh variabel lain di luar model penelitian ini.

\section{Uji Stabilitas Model}

Pengujian stabilitas structural model dapat dibedakan atas dua, CUSUM (Cumulative Sum of Recursive Residual) dan CUSUMQ (Cumulative Sum of Square of Recursive Residual). Berikut ini yaitu hasil pengujian CUSUM dengan variabel pertumbuhan ekonomi sebagai variabel dependent.

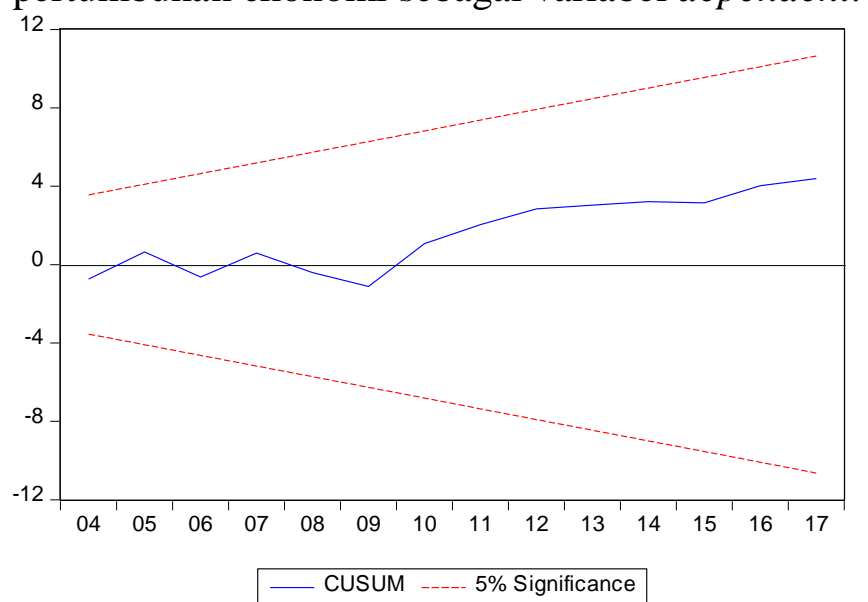

Gambar 2

\section{Pengujian CUSUM Test}

Berdasarkan Gambar 2, hasil uji CUSUM dapat di jelaskan yaitu plot kuantitas Wr tidak berada diatas garis batas pada tingkat signifikan $5 \%$, plot tersebut membentuk suatu garis linear.

\section{Pembuktian Secara Simultan}




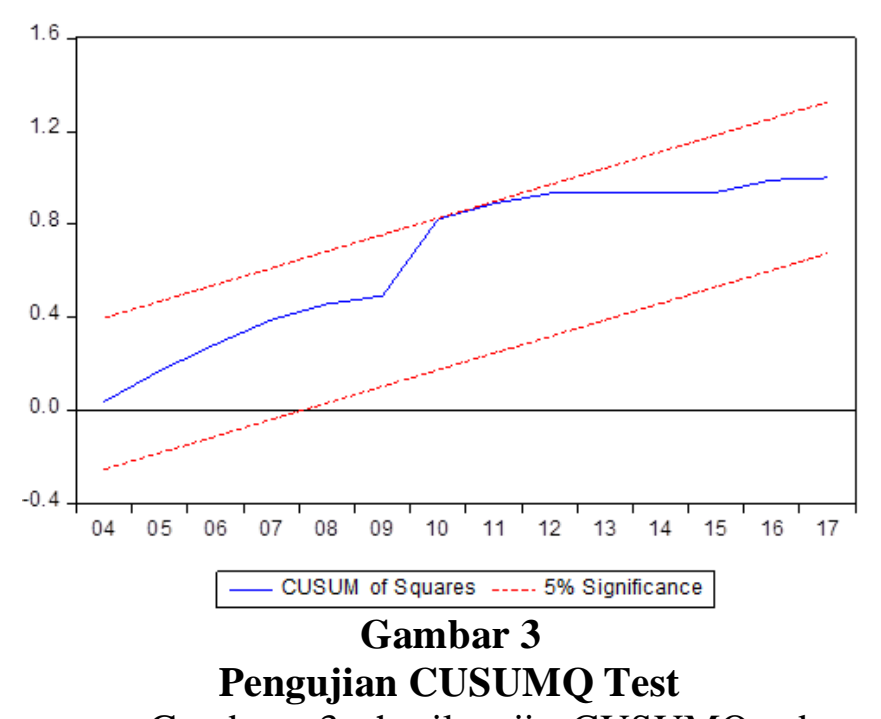

Gambar 3 hasil uji CUSUMQ dapat dijelaskan yaitu plot kuantitas $\mathrm{Sr}$ tidak berada diatas garis batas pada tingkat signifikan 5\%, plot tersebut membentuk suatu garis linear. Berdasarkan hasil kedua uji stabilitas model diatas bisaditarik kesimpulannyajika koefisien hasil regresi bersifat stabil.

\section{Pembahasan}

Berdasarkan hasil penelitian jangka pendek menggunakan model ARDL variabel jumlah uang beredar berpengaruh negatif dan signifikan terhadap pertumbuhan ekonomi di Indonesia. Hasil pengujian ini sesuai dengan pendapat yang dikemukakan oleh Rhensy,dkk (2016) bahwa Jumlah uang beredar mempunyai pengaruh negatif terhadap pertumbuhan ekonomi.Pengaruh tersebut signifikan secara statistik pada tingkat kepercayaan $90 \%$ tetapi tidak sesuai dengan teori. Dan variabel jumlah penduduk berpengaruh positif dan signifikan terhadap pertumbuhan ekonomi di Indonesia. Hasil pengujian ini sependapat dengan hasil penelitian yang dilakukan oleh Widarjono (1999), bahwa Pertumbuhan Penduduk mempunyai hubungan yang positif terhadap Pertumbuhan Ekonomi.

Nilai ECT/CointEq (-1) bertanda negatif dan signifikan artinya bahwa apabila terjadi guncangan terhadap variabel jumlah uang beredar dan jumlah penduduk maka variabel pertumbuhan ekonomi membutuhkan waktu 3 tahun untuk penyesuaian ketidakseimbangan dalam jangka panjang. Atau dengan kata lain koefisien ECT bertanda negatif dan signifikan artinya pertumbuhan ekonomi mengalami penyesuaian keseimbangan jangka pendek menuju keseimbangan jangka panjang dengan kecepatan 1,23 persen per bulan.

\section{KESIMPULAN DAN SARAN \\ Kesimpulan}

Dari hasil penelitian yangdilakukan maka dapatdisimpulkan beberapa kesimpulan diantaranya adalah sebagai berikut:

1. Dalam analisis jangka pendek dan jangka panjangjumlah uang beredar berpengaruh negatif dan signifikan terhadap pertumbuhan ekonomi di Indonesia.

2. Dalam analisis jangka pendek dan jangka panjang jumlah penduduk berpengaruh positif dan signifikan terhadap pertumbuhan ekonomi di Indonesia.

\section{Saran}

Berdasarkan kesimpulan yang sudah dikemukakan di atas maka yang menjadi saran dalam penelitian ini yaitu:

1. Pemerintah Indonesia diharapkan dapat membuat kebijakan yang bisa menekan tingkat jumlah uang beredar sehingga tidak sampai menyebabkan inflasi yang tinggi dan menyebabkan pertumbuhan ekonomi menurun.

2. Untuk Peneliti yang melakukan penelitian sejenis, penulis menyarankan agar menambah variabel lain yang mempengaruhi pertumbuhan ekonomi dan menggunakan metode penelitian lain dalam menganalisis data.

\section{DAFTAR PUSTAKA}

Alghofari, F. (2007). Analisis Tingkat Pengangguran di Indonesia Tahun 1980007.

Badan Pusat Statistik. (2010). Pengertian Kependudukan https://www.bps.go.id/subjek/view/id/12

Boediono. (2008). Ekonomi Moneter.

Chairany, M. (2010). Analisis Jumlah Penduduk Kecamatan Padang Bolak pada Tahun 2012.

Ervani, E. V. A. (2004). Analisis Faktor-Faktor yang Mempengaruhi Pertumbuhan Ekonomi Periode tahun 1980.1-2004.IV. 7(2), 17-18.

Gujarati, D. N. (2006). Dasar-Dasar Ekonometrika. Edisi Ketiga. In Jakarta: Erlangga. 
Gujarati, D. N., \& Porter, D. C. (2012). DasarDasar Ekonometrika. Edisi Lima. In Jakarta: Salemba Empat.

Mankiw, N. Gregory. (2006). Makro Ekonomi Edisi Keenam. Jakarta: Erlangga.

Natsir, M. (2014). Ekonomi Moneter dan Kebanksentralan. Jakarta: Mitra Wacana Media.

Nuri Angraini.2012. Analisis Pendapatan Nasional,Tingkat Suku Bunga SBi Dan Giro Wajib minimum Terhadap Jumlah Uang Beredar di Indonesia.

Setiono, Dedi NS. (2010). Ekonomi pengembangan Wilayah. Teori dan Analisis. Lembaga Penerbit fakultas ekonomi Universitas Indonesia.

Sukirno, Sadono, 2005. Mikro Ekonomi Teori Pengantar, Edisi Ketiga, Raja Grafindo Persada, Jakarta.

Sukirno, Sadono. (2010). Makroekonomi Teori Pengantar Edisi Ketiga. Jakarta: Rajawali Pers.

Tiwa, F.R., Rumate, Vekie. \& Tenda, A. (2016). Pengaruh Investasi, suku Bunga Sertifikat Bank Indonesia (SBI) dan Jumlah Uang Bereda terhadap Pertumbuhan Ekonomi Indonesia Tahun 2005-2014.

Todaro, Michael P dan Smith, Stephen 2003. Pembangunan Ekonomi di Dunia Ketiga. Jakarta: Erlangga.

Widarjono, A. (2007). Ekonometrika Teori dan Aplikasi untuk Ekonomi dan Bisnis, Edisi Kedua, Cetakan Kesatu, Penerbit Ekonisia Fakultas Ekonomi UII Yogyakarta.

Widarjano, A. (2013). Ekonometrika. Edisi Keempat. In Yogyakarta.

Yuliadi, Imamudin., (2008), Ekonomi Moneter, Cetakan I, PT. INDEKS, Jakarta.

https://ekonomi.kompas.com/read/2018/02/05/113 820026/ekonomi-indonesia-2017-tumbuh507-persen-tertinggi-sejak-tahun-2014 